\title{
ALCYONIUM? BOTRYOIDES.
}

O

CHARACTER SPECIFICUS.

ALCYONIUM? (Spongia ?) flavo-purpurafcens, caule craffo ftupofo, fuperne ramofo, ramulis denfiffime congeftis.

SPONGIA floribunda? Sp. amorpha, fafciculis ramofis confluentibus paleaceo-tomentofis, apice craffioribus obtufis.

Pall. el. zooph. p. 378 . छे p. 434 addend.

Pulchri et mirabilis Alcyonii quod neminem opinamur defcripfiffe, veram magnitudinem depinximus. Litora incolit Auftralafiæ, infulæ præcipue quæ Norfolcia dicitur, et profunde fub aquis merfum adhæret rupibus. Caulis ramique majores flavo-pallent, ramulis minoribus vivide rubentibus feu purpureis. Totum Alcyonium molliculum, fed tenax; tactu durum, fi exaruerit ; et videtur componi omnino e fibris parvulis, vermiculatis, quarum extremitates acuminatæ. Racemi qui terminales vocantur conftant e tubulis divifis et fub-divifis, fingulis quafi in calycem leviter expanfum definentibus; bracteamque, feu foliolum florale (ut phyfice loquar) non male fimulantibus, qui forfan munimento fint 
lli zoophyti parti qua animalis effe videtur; organo nempe flori-formi, flavo-pallenti, ex iifdem fibris vermiculatis confecto quibus reliquæ partes, fed minoribus et confertioribus. Conftat hæc quafi corolla feu pars hydræformis e quinque vel fex fegmentis oblique acuminatis et convergentibus, foramen tubulatum habentibus, per quod ipfi Alcyonio nutrimentum poffit adminiftrari. Licet tamen conjicere, nec inepte, polypos feu hydras (fi quæ revera fint) intra tubulos quos fupra memoravimus, fefe fubduxiffe, calycibus tantum five foraminibus externis in confpectu relictis. $\Lambda$ tranfverfo caulis fegmento manifeftum erit Alcyonium effe veluti cancellatum et leviter compactum, cavitatibus omnibus in longitudinem ab imo ad fummum continuatis.

Elegans Alcyonii botryoidis fpecimen Societati Linnæanæ Londinenfi donavit Dominus Paterfon, coloniæ Britannicæ apud Auftralafiam Subpræfectus.

Figura inferior monftrat fpecimen in fpiritu vini diu affervatum : tertia partem racemi externi magnitudine aucti ut corolliformes terminationes manifeftius pateant : quarta unam e fibris vermiculatis e quibus totum componitur, magnitudine auctam. 


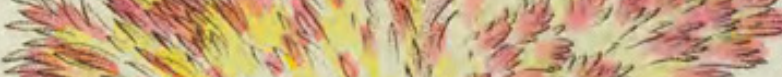
होe
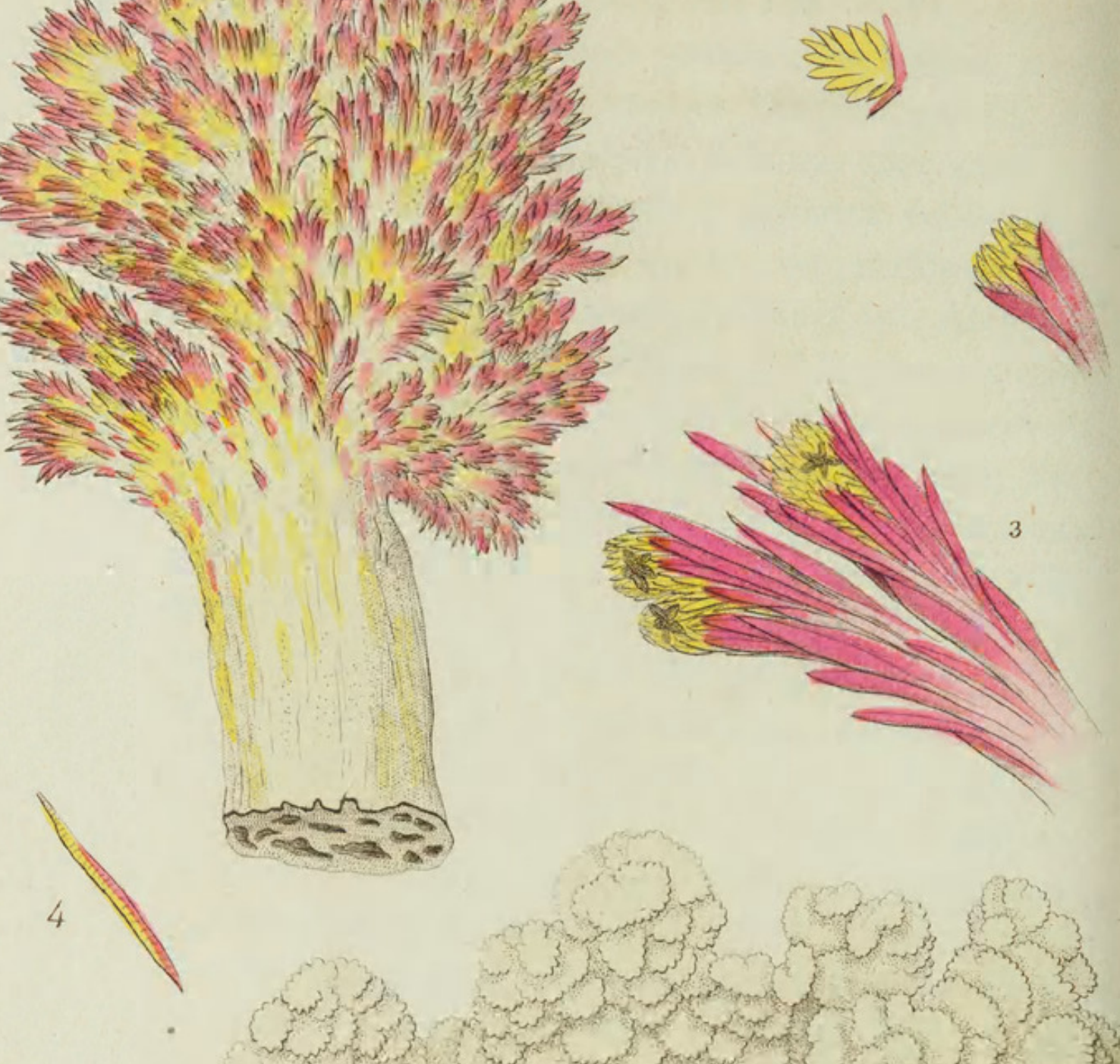

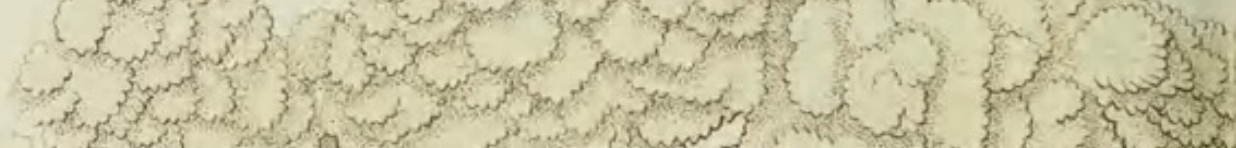

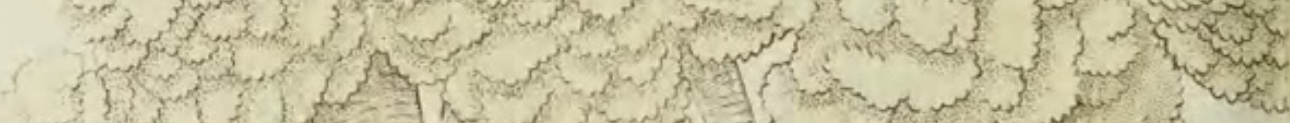

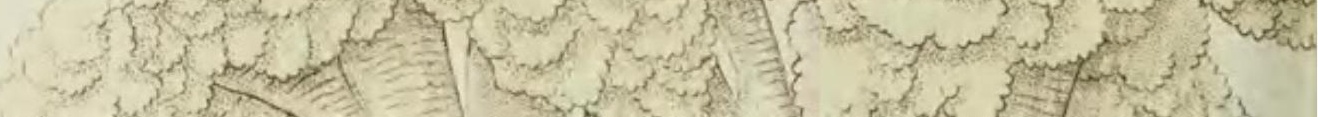

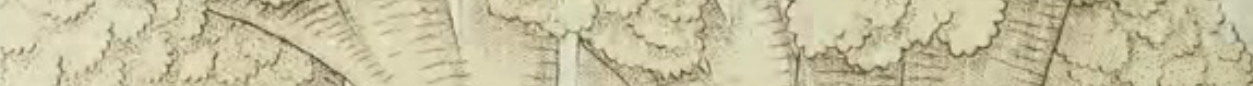

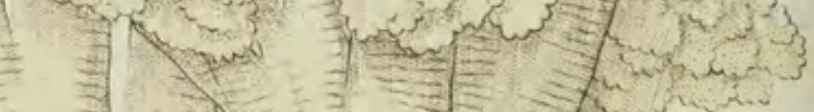

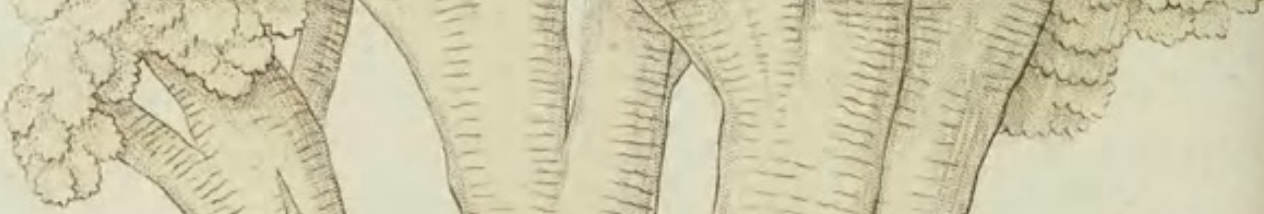

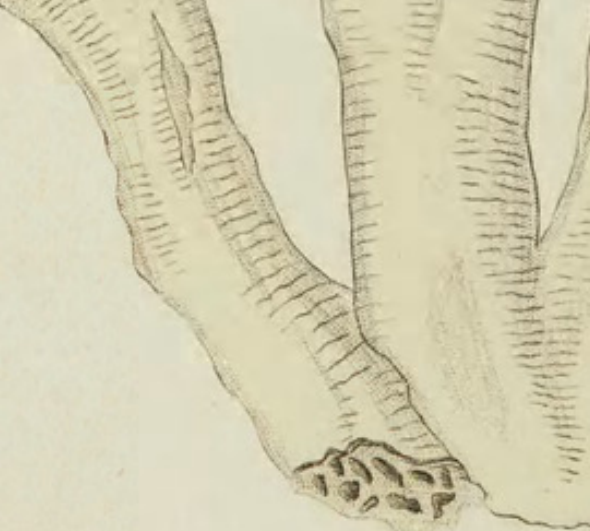$$
\Sigma \equiv\left(\frac{1}{7}\right)
$$ 


\section{CAULIFLOWER ALCYONIUM.}

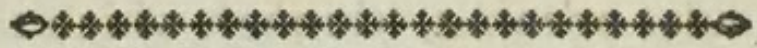

SPECIFIC CHARACTER.

Yellow-purple ALCYONIUM ? (Sponge ?) with thick, ftupofe ftem, ramifying on the upper part; with very thickly-crowded branchets.

This elegant and fingular Alcyonium feems a fpecies hitherto undefcribed, and is a native of the coafts of New Holland, and more particularly of Norfolk Ifland; adhering to rocks at a confiderable depth. The plate reprefents it in its natural fize. The color of the ftem and principal branches is pale yellow: of the fmaller ramifications bright crimfon or purple. The fubftance of the whole is foftim, but tough; harfh to the touch in its dried ftate; and feemingly compofed entirely of fmall, thickin, vermicular fibres with attenuated or fharpened extremities. The terminal clufters confift of divided and fubdivided tubular proceffes, each ending in a calycular, flightly-expanded part, not ill refembling a bractea, and forming a kind of guard for what appears to be the animal part of the zoophyte; viz. a kind of flower-Phaped organ of a paleyellow color, and compofed of the fame kind of thickifh vermicular fibres with the reft, but on a fmaller fcale, and fomewhat more clofely difpofed. 
This flower, or polype-like part confifts of five or fix obtufely-acuminated, converging fegments, leaving a tubular opening, through which the proper nutriment may be conveyed to the whole. It is however no improbable fuppofition that the real polypes, (if fuch exift) may have withdrawn themfelves into the lower parts of their refpective tubular branches, leaving only the external calyces in view. A tranfverfe fection of this Alcyonium thews it to be of a cancellated or loofely-compacted fabric, the hollows all running in a longitudinal direction from the bottom upwards.

An elegant fpecimen of this Alcyonium was fometime fince prefented to the Linnxan Society by Colonel Paterfon, Vice-Governor of the Englifh fettlement in New Holland.

The lower figure reprefents a fpecimen preferved for a confiderable time in fpirit of wine.

Fig. 3. A magnified view of one of the exterior ramifications, in order to thew the flower-like terminations.

Fig. 4. Magnified view of one of the vermicular fibres of which the whole is compofed. 


\section{$2 \mathrm{BHL}$ Biodiversity Heritage Library}

Shaw, George. 1799. "Cauliflower Alcyonium, Alcyonium botryoides [PI. 376]." The Naturalist's Miscellany 10(CXV), https://doi.org/10.5962/p.304558.

View This Item Online: https://www.biodiversitylibrary.org/item/276641

DOI: https://doi.org/10.5962/p.304558

Permalink: https://www.biodiversitylibrary.org/partpdf/304558

\section{Holding Institution}

Museums Victoria

\section{Sponsored by}

Atlas of Living Australia

\section{Copyright \& Reuse}

Copyright Status: Public domain. The BHL considers that this work is no longer under copyright protection.

This document was created from content at the Biodiversity Heritage Library, the world's largest open access digital library for biodiversity literature and archives. Visit BHL at https://www.biodiversitylibrary.org. 